\title{
Ecological Restoration of the West Lake in Hangzhou, China
}

An Introduction to the 2001 Ecological Conceptual Planning and a Review of its Implementation

\author{
Tianqing Luo $^{1 *}$ \\ 1 Department of Landscape Studies, College of Architecture and Urban Planning, Tongji \\ University \\ *Corresponding Author,Email: luotq@tongji.edu.cn
}

Received: Feb 21, 2018; Accepted: May 27, 2018

Keywords: Ecological Planning, Conceptual Planning, Planning Implementation, Water Environment Restoration, West Lake in Hangzhou

\begin{abstract}
In China, at the beginning of the 21st century, conceptual planning became a popular type of strategic planning. However, it tended to address issues more relevant to development opportunities, industrial structures and spatial layouts, rather than the ideas of environment and ecology. Instead, Tongji University's conceptual planning for the West Lake in Hangzhou, proposed in 2001, focused on the restoration of water environments. It regarded environmental improvement as a precondition for further development of tourism and the economy. Although this plan did not win the bid at the time, the lake's ecological restoration from then onward incorporated all of its proposed concepts. As a result, the lake's ecosystem has been restored successfully. This paper introduces the plan, discusses its main ideas and contextually reflects upon the implementation of conceptual ecological planning. In addition to the need to be connected to development actions or statutory planning, relying on adequate multidisciplinary technical support and rationally addressing local development contributes to best practices for ecological conceptual planning.
\end{abstract}

\section{INTRODUCTION}

\subsection{The West Lake Watershed and the National Historic Relics and Scenic Site}

West Lake in Hangzhou, China is famous for its beautiful shan-shui environment, considered to be a paradise. It was one of the first National Historic Relics and Scenic Sites (NHRSSs) created in China in 1982; these relics and scenic sites are equivalent to national parks in western countries and have been established to protect not only distinctive natural resources but also the various traditional cultures. The total area of the NHRSS is 14.8 thousand acres, including the lake in the eastern part of the site. The lake occupied 1,400 acres in the 1990s, with a basin of 6,600 acres, and it is surrounded by several hills to the north, west and south. Qiantang River flows along the southern boundary of the NHRSS (Figure 1).

The watershed is isolated from the urban area to the east (Figure 1). The elevation of the basin bottom is higher than that of the plain, where the 
urban area is located. The water level of the lake is controlled at $7.17 \mathrm{~m}$ (Yellow Sea Datum 1956), much higher than the other water systems in the city. This water level makes it impossible to obtain a water supply from the surrounding area. The average depth of the lake, as measured in the 1990s, is $1.97 \mathrm{~m}$.

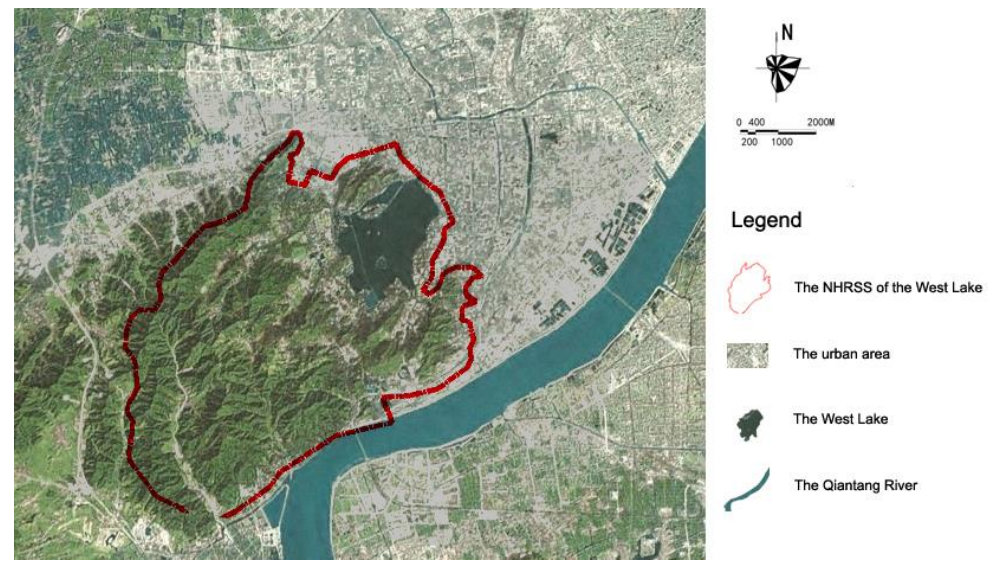

Figure 1. The NHRSS of the West Lake in Hangzhou, China (with the lake area in the 1990s)

\subsection{The Momentous Landscape Transformations and the Recent Environmental Dilemma of the Lake}

The West Lake was originally a lagoon and gradually became a fresh water lake after being separated from the East China Sea. Since more than 1600 years ago, when first recorded, the lake has experienced several momentous landscape transformations. Each transformation repeated a history of silt accumulation, dredging, and then landscaping to create successive beautiful islands and causeways. By the 1990s, the lake's water area had shrunk to half of its first recorded size. The loss of water area weakened the lake's ecological functions and converted its natural system into a maintained one.

During the $20^{\text {th }}$ century, the lake's water quality gradually deteriorated because of urbanization, tourism, agricultural and industrial development, both inside and outside the NHRSS. Dignitaries and the literati built villas around the lake to enjoy its scenic landscape and to pursue hermit lifestyles. A significant number of tourists have been attracted to the lake, and visitors became not only fortune-makers but also waste-creators. The west valleys of the lake are the origin of the famous green tea, i.e., Longjing Tea, and the cultivation of the tea consumes a substantial amount of chemical fertilizer and pesticides, a considerable amount of which flows into surface runoff and eventually into the lake. In the second half of the $20^{\text {th }}$ century, small factories invaded the villages pursuing economic development. In the 1940s, the lake became eutrophic and then rapidly deteriorated to become hypertrophic during the 1960s and 1970s. In the 1980s, the local government had to launch a comprehensive water management project, endeavoring to stop the progress of deterioration, but was unable to achieve any fundamental changes. 


\subsection{The Background of Conceptual Planning}

In 2001, the local government invited experts in landscape architecture (LA) from Chinese universities' best LA programs for conceptually planning development in the western area of the lake. The intention of the invitation was to study the feasibility of the new development before launching an expansion of the water area to the west plains of the lake (Figure 2). It was expected that the expansion would lead to further landscaping of the shan-shui spaces, attract visitors to the pathless west area, and improve the lake's environmental quality.

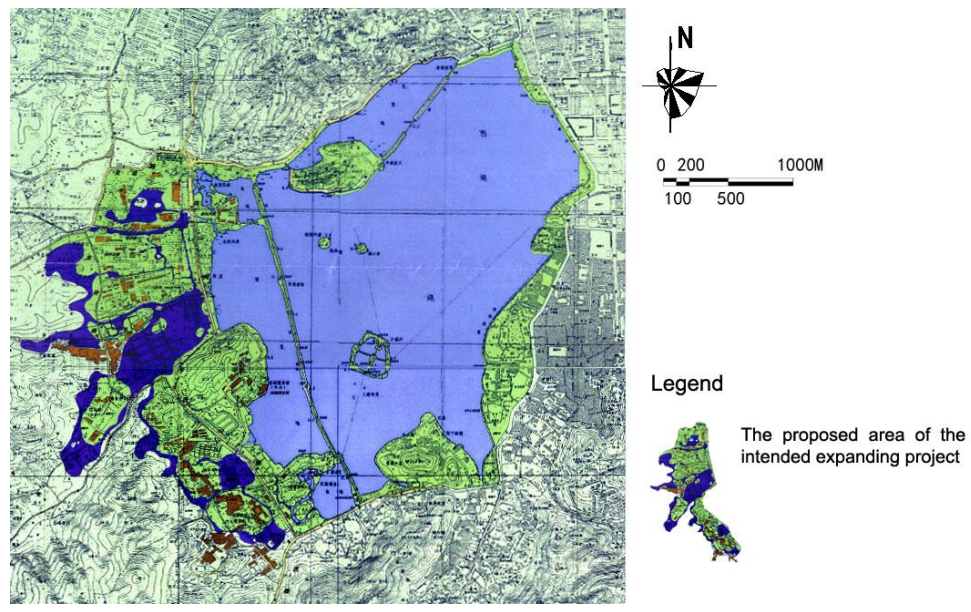

Figure 2. The map of intended development proposed by the Hangzhou Landscape Architecture Design Institute (in: The reference materials provided by the local government)

Tongji University was invited and developed a water-restoration-oriented plan. Although it did not win the bid under the circumstances at the time, as one of the first ecological plans in China, it had a long-lasting influence on the lake's ecological restoration. Incidentally, the lake's restoration practices were hugely successful. This paper will introduce the plan, discuss its main ideas, and reflect upon the implementation of conceptual ecological planning in this context.

\subsection{Conceptual Planning and Ecological Planning in China}

Conceptual planning creates concepts, at either the macro or micro scale, to guide potential development and solve essential problems (Jie \& Bingyao, 2003). In the 1960s, in many countries, the practice of conceptual planning emerged from strategic planning, for example the conceptual plans $\left(1^{\text {st }}\right.$ edition delivered in 1971) for Singapore, Tomorrow's Canberra (beginning in 1965 and finished in 1970) in Australia, and structural plans for cities in the UK (after 1968) (Chen, B., 2003). Intercountry and interregional practices vary greatly because cities were at different stages of development and thus faced different problems (Zhao, Y., 2001). In China at the beginning of the $21^{\text {st }}$ century, markets began to replace rigid plans and distribute resources, which brought various development opportunities, and planners were asked to participate in the decision-making processes exploratively (Zhao, Y., 2001). Conceptual planning then became a popular form of strategic planning, focusing on problem-oriented studies and pursuing various options for instant rapid urbanization and sustainable 
development (Chen, B., 2003). Such plans have no legal validity and can produce more audacious ideas to help decision-making and create legal plans (i.e., comprehensive plan and zoning plan) (Chen, B., 2003). Thus, local governments scrambled to organize conceptual planning for development in the new millennium (Zhao, M. \& Luan, 2003).

Ecological planning offers a comprehensive methodology that allows planners and resource managers to better understand the nature and character of land and resources and therefore make better decisions about its appropriate use or management (Steiner \& Brooks, 1981). In western countries, theory and practice associated with ecological planning grew rapidly before World War II but disappeared in the literature after the war, and then began attracting increasing attention from the late 1960s when environmental problems became serious (Ouyang \& Wang, 1995). Thereafter, environmental conservation became the most important objective among multiple developing objectives, and ecological planning methods were applied in conceptual planning to develop conservation strategies.

However, in China, most early conceptual planning tended to address issues more related to development opportunities, industrial structures and spatial layouts, rather than the ideas of environment and ecology (Chen, B., 2003). This was partly due to the lag of ecological planning practices. Although the harmony between humans and nature existed in a variety of China's ancient cities and gardens, the country's modern cities turned to human-centered spatial organization and abandoned their traditional heritage. After the rapid industrialization and urbanization, environmental problems emerged in the 1980s. It was therefore in the late 1990s that ecological planning theory and methods were introduced in China (e.g., Ouyang \& Wang, 1995; Yu \& Li, 1997).

Tongji University's conceptual planning for West Lake focused on the restoration of the aquatic environment and regarded environmental improvement as a precondition for encouraging tourism and economic growth. In China, when a comprehensive plan is developed from a conceptual one, there is a 20 year delay before its effects can be assessed. Sixteen years have passed since the conceptual planning of West Lake was finished, and a good window is now opening to examine and conclude the effects of the plan.

\section{CONCEPTS}

\subsection{What is the Essential Problem, Recreational or Ecological?}

Due to the adjacency of the NHRSS and the urban area, the major problem confronting West Lake was how to achieve a balance between the conservation of the scenic area and local development, including from urbanization and the tourism industry. The expanding urban area and increasing construction of skyscrapers had broken the previous harmony between the lake and the city. Urban construction continued encroaching on the buffer zone between the NHRSS and the urban area, sometimes even impacting scenic areas. In the last Master Plan, it had been suggested that the NHRSS should accommodate no more than 21.25 million tourists per year. However, the actual number of visitors reached almost 21.72 million 
per year by the end of the 1990s, putting tremendous pressure upon the lake's ecosystem. More importantly, more than half of the visitors are spontaneous vacationers, whose behavior is hard to predict. This makes it difficult for the government to conduct overall tourism management.

These negative impacts aggravated the deterioration of the lake's ecological environment. Due to the expansion of land used for construction within and outside of the NHRSS, increasing use of water in production and households, stone embankments, and the combined sewerage system, the water table in the watershed had dropped significantly. Other consequences, such as decreasing spring and runoff volumes, dried-up streams in the dry season, and the loss of the ecosystem's purification capacity following longterm pollution, had also emerged. The heavy load of pollutants and long retention time of the lake were the two main reasons for the exacerbation of eutrophication in West Lake.

A healthy West Lake ecosystem not only guarantees the NHRSS's natural landscape but also improves the city's environment. More importantly, it lays the foundation for the sustainable development of the city's tourist industry. However, simply restricting urban development and tourism for environmental improvement was not an attractive option. The most urgent and viable initiative would have been to improve the lake's ecosystem to enhance its environmental capacity. Only in this way could benign development of the NHRSS, tourism and city development be realized.

\subsection{How to Solve it: by Engineering Techniques or Landscaping-Balanced Solutions?}

From 1949 to 2001, the government invested approximately 600 million RMB yuan into restoring West Lake, of which nearly 500 million had been used for the treatment of its eutrophication. All the main remediation measures were oriented by engineering techniques, including (1) dredging silt on the lake bottom, (2) reshaping the natural lakeshore with stone embankments, (3) draining sewerage from the villages and (4) diverting water from Qiantang River to accelerate the water flow in the lake. The first two measures attempted to control erosion and prevent the lake from silting up, while the latter two measures were designed specifically to address the two major issues that caused the lake's eutrophication, i.e., heavy pollution and long retention time of the lake (Table 1). Although the rapidly deteriorating water quality was effectively suppressed by the treatment, the overall water quality was not significantly improved. In 2001, West Lake was still severely eutrophicated.

Table 1. Comparison of the main remediation measures

\begin{tabular}{llll}
\hline Measure & Period & $\begin{array}{l}\text { Investment } \\
(10,000 \mathrm{RMB})\end{array}$ & Effect \\
\hline $\begin{array}{l}\text { Dredging Silt } \\
\text { on the Lake } \\
\text { Bottom }\end{array}$ & $\begin{array}{l}1953 \sim 1958 \\
1978 \sim 1982\end{array}$ & $\begin{array}{l}453.83 \text { in total } \\
200.00 \text { in total } \\
22.50 \text { per year }\end{array}$ & $\begin{array}{l}\text { It is the most straightforward but } \\
\text { expensive way to solve the lake's } \\
\text { sedimentation. In the process of dredging, } \\
\text { a large amount of interstitial water } \\
\text { containing Fe2+, N and P would have } \\
\text { been released, which would have caused } \\
\text { short-term adverse consequences upon } \\
\text { the ecosystem. }\end{array}$ \\
Reshaping the & $1953 \sim 1965$ & N/A & It maintained the stability of the lakeshore
\end{tabular}




\begin{tabular}{|c|c|c|c|}
\hline Measure & Period & $\begin{array}{l}\text { Investment } \\
(10,000 \mathrm{RMB})\end{array}$ & Effect \\
\hline $\begin{array}{l}\text { Lakeshore } \\
\text { with Stone } \\
\text { Embankments }\end{array}$ & $1976 \sim 1980$ & 144.80 in total & $\begin{array}{l}\text { and blocked a large amount of sediment } \\
\text { in surface runoff from drifting into the } \\
\text { lake. However, it hindered the percolation } \\
\text { of the ground water from the surrounding } \\
\text { hills into the lake, and the original natural } \\
\text { lakeshore disappeared. }\end{array}$ \\
\hline $\begin{array}{l}\text { Draining } \\
\text { Sewerage } \\
\text { from the } \\
\text { Villages }\end{array}$ & $1978 \sim 1981$ & 70.00 in total & $\begin{array}{l}\text { It is the most economically efficient } \\
\text { method that reduced a significant amount } \\
\text { of sewerage within a short period and } \\
\text { thus transformed the lake's pollution } \\
\text { sources from point to non-point. } \\
\text { However, due to the rainwater in the } \\
\text { villages not having been separated and } \\
\text { drained at the same time, this measure } \\
\text { reduced the amount of water entering the } \\
\text { lake. This measure cannot address non- } \\
\text { point source pollution from the vast } \\
\text { farmlands and fishponds outside of the } \\
\text { villages. }\end{array}$ \\
\hline $\begin{array}{l}\text { Diverting the } \\
\text { River Water } \\
\text { to Flush the } \\
\text { Lake Water }\end{array}$ & $\begin{array}{l}\text { 1985 1986 } \\
1987 \sim\end{array}$ & $\begin{array}{l}1169.00 \text { in total } \\
30.00 \text { per year }\end{array}$ & $\begin{array}{l}\text { It is a huge project and needed many } \\
\text { investments, and it violated the laws of } \\
\text { nature. Since Qiantang River in } \\
\text { Hangzhou is affected by tides, the direct } \\
\text { diversion of a large amount of river water } \\
\text { may have changed the chemical } \\
\text { characteristics of the lake water. Given } \\
\text { the poor river water quality, the main } \\
\text { purpose of the diversion was to instantly } \\
\text { dilute the lake water and reduce the lake } \\
\text { retention time. However, in the long run, } \\
\text { it may cause salinization in West Lake } \\
\text { freshwater ecosystem and be of no help in } \\
\text { restoring the resilience of the lake. }\end{array}$ \\
\hline
\end{tabular}

The abovementioned measures shifted the main environmental problems of West Lake from serious siltation and point source pollution to large-scale non-point source pollution. Pollutants were carried into the lake by either the streams from the surrounding valleys or the diverted water from the river. The quantity of pollutant increased with greater water flow into the lake (see Figure 3, the bigger the arrow size, the larger the inflow). Thus, in different parts of the lake (Figure 4), due to the different quantity of the input pollutants, and the uneven distribution of the water flow, the water quality differed significantly (see Figure 3). For instance, higher water quality was found in both the small south lake and the pools on San-tan-yinyue Island. While the water had been directly diverted into the small south lake to dilute its pollution, a special small ecosystem had been established to keep the island pools clean. Other parts of the lake, including the west inner lake, the outer lake and the Yue lake, had poorer water quality. Moreover, the north inner lake had the worst water quality because it received a larger amount of pollutants and is located where there is no inflow of diverted water. 


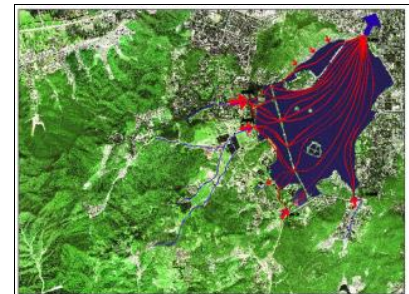

Logens

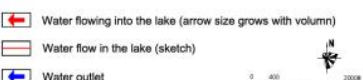

$\square$ water outeot
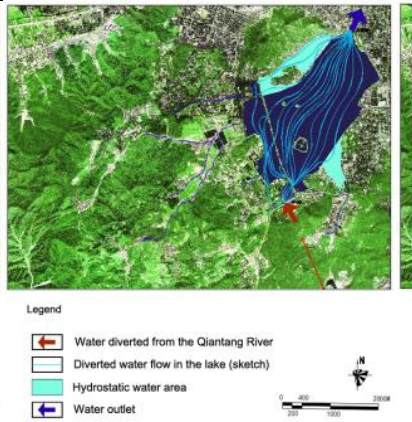

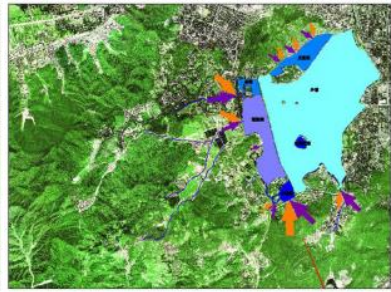

lepens

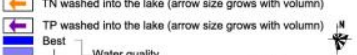

(a) Inflows from the streams (b) Inflow of the diverted water (c) Pollutant inflows and water quality in different parts of the lake

Figure 3. The association of non-point source pollution and the water quality in different parts of the lake (from the data in Investigation of Eutrophication in the West Lake and Research on the Comprehensive Management Planning in the reference materials provided by the local government)

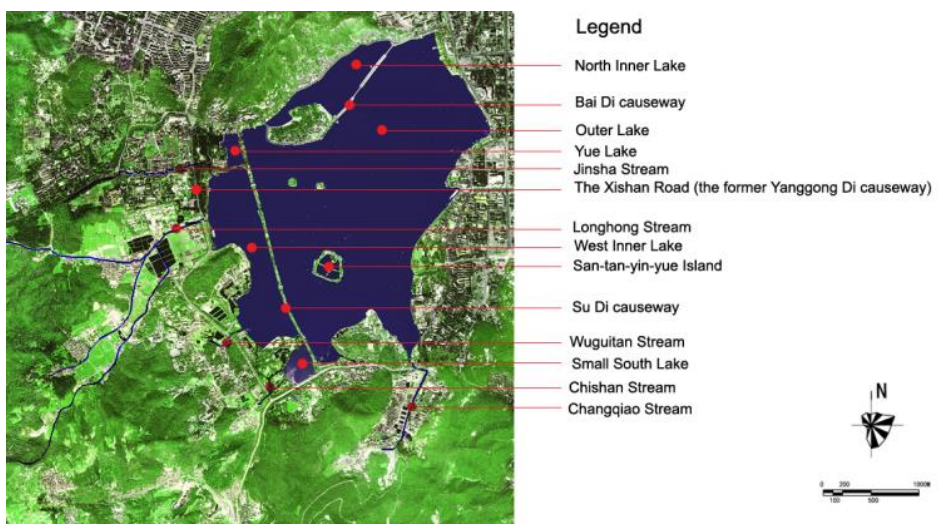

Figure 4. The different parts of the lake

To realize a sound improvement of the aquatic environment in the West Lake, it is necessary to restore a normal water exchange mechanism in the basin and improve the quality of the water entering the lake. In this regard, the remediation measures that had been practiced are not enough, and future actions should pay more attention to the improvement of the diverted water and the purification of the runoff (Table 2).

Table 2. Suggested Measures for the Eutrophication Treatment

\begin{tabular}{lll}
\hline Measure & Objective & Methods \\
$\begin{array}{l}\text { Improvement of } \\
\text { the } \\
\begin{array}{l}\text { Implementation } \\
\text { of Water }\end{array}\end{array}$ & $\begin{array}{l}\text { To optimize the water inlet } \\
\text { layout, increase diversion } \\
\text { volume and eliminate } \\
\text { hydrostatic water areas in } \\
\text { the lake }\end{array}$ & $\begin{array}{l}\text { Designing a proper annual water diversion } \\
\text { allocation plan, pre-treating the diverted } \\
\text { water, increasing the diverted volume per } \\
\text { year to the target figure and optimizing } \\
\text { water flows to motivate hydrostatic water } \\
\text { areas }\end{array}$ \\
$\begin{array}{l}\text { Purification of } \\
\text { the Runoff } \\
\begin{array}{l}\text { Entering the } \\
\text { Lake }\end{array}\end{array}$ & $\begin{array}{l}\text { To purify the water in the } \\
\text { streams before flowing into } \\
\text { the lake and restore the } \\
\text { natural self-purification } \\
\text { capability of the water }\end{array}$ & $\begin{array}{l}\text { Selecting sites in the west and south plains } \\
\text { to build aquaculture ponds that can treat the } \\
\text { stream water }\end{array}$ \\
\hline
\end{tabular}


An aquaculture pond system can form a natural and serene landscape environment. The aquatic plants in the ponds will provide long-term purification and improve the ecosystem of the lake. In this sense, such a system is a landscaping-balanced solution. In ancient dynasties, similar landscaping-balanced practices had been used repeatedly. All of the momentous dredging practices simultaneously took into account landscape construction. When they endeavored to solve the then imminent problem successfully (i.e., to prevent the lake being silted up), further construction of the Bai Di causeway, the Su Di causeway, the Yanggong Di causeway (i.e., Xishan Road along the west bank of the lake in the 1990s) and the three islands (see Figure 4) was planned. The causeways and islands form a beautiful landscape pattern called the Two Dikes and Three Islands. Moreover, the construction of aquaculture ponds can also develop recreational spaces and reduce the land use for institutional, residential and industrial purposes. This better land use practice is simultaneously beneficial for ecological conservation and tourism development.

\subsection{The Planning Concepts}

The proposed planning strategies were therefore the following:

1) In addition to the west plains, the southern region should be taken into consideration for overall conservation of the lake at the watershed scale in the new development round.

2) Water diversion from Qiantang River is a measure relying on external force, so while it will help to restore the natural resilience of the lake, it can never be a long-term strategy.

3) The ecological benefits should always be the primary consideration; these benefits guarantee the long-term development of the lake, the NHRSS and the entire city.

When planning the lake's water exchange system, the water supply and flood control must be considered in an integrated manner. There are three available water sources for the expansion of the water area: streams from the valleys, water from West Lake and water diverted from Qiantang River (Table 3). The planning suggested that all three sources should be flexibly used to maximize the ecological and landscape benefits of the aquaculture ponds. When the streams dry, the aquaculture ponds can still work with the water from either the lake or the river. The main difficulty in treating nonpoint source pollution is stormwater control. The flood brings a large quantity of sediment and pollutants in such a short period of time, making purification difficult. Additionally, sediments in the ponds would be washed into the lake. If a flood gate was to be installed between the pond and the lake, it would impede recreational activities and traffic on the lake. If the flood water was to be discharged directly into the lake through the spillway, there would be no way to purify the water. Therefore, the suggested plan was to design cascading aquaculture ponds for each stream, meeting with the spillway. It also involved installing control gates between the primary and secondary ponds and setting different water control levels to increase the flood storage capacity. Different tributaries in the basin contain different quantities of floodwater. Downstream, the land available for constructing the purification ponds also differs significantly. In this case, a connected system of aquaculture ponds can realize better flood control for the whole basin. Moreover, owing to the concentration of the catchment areas in the basin, it would take much less effort to build ditches to connect ponds than excavate more ponds. 
Table 3. Evaluation of available water sources

\begin{tabular}{lll}
\hline Water Source & Advantage & Disadvantage \\
\hline Streams & A direct water source & $\begin{array}{l}\text { An unstable water source because sufficient } \\
\text { runoff only occurs in the wet season, i.e., } \\
\text { only } 10 \% \text { of the year. During the other } \\
\text { seasons, the streams often dry up, which } \\
\text { would hinder the purifying effect of the } \\
\text { purification ponds }\end{array}$ \\
$\begin{array}{lll}\text { Water from } \\
\text { the Lake }\end{array}$ & $\begin{array}{l}\text { As it is an adjacent source, } \\
\text { can be utilized on demand } \\
\text { without any construction cost }\end{array}$ & $\begin{array}{l}\text { When the streams dry up, the expanded } \\
\text { water areas could become new hydrostatic } \\
\text { areas }\end{array}$ \\
$\begin{array}{l}\text { Water } \\
\text { Diverted from } \\
\text { the Qiantang } \\
\text { River }\end{array}$ & $\begin{array}{l}\text { Can be fed into the } \\
\text { aquaculture ponds and link } \\
\text { the ponds into a system to } \\
\text { improve the stability of both } \\
\text { runoff supply and the ponds } \\
\text { purifying effect }\end{array}$ & $\begin{array}{l}\text { It need to be connected to the aquaculture } \\
\text { ponds to increase the annual diversion } \\
\text { volume, which will be expansive and } \\
\text { construction-intensive }\end{array}$ \\
\hline
\end{tabular}

In summary, the concepts of the suggested development were as follows:

1) Constructing aquaculture ponds downstream of each stream to provide an integrated water purification process by a system that is comprised of spillways, primary purification ponds, secondary purification ponds and the lake.

2) Connecting the primary purification ponds for different streams to each other and introducing the water diverted from Qiantang River as a supplementary water source to wash away the pollution from runoff.

3) Connecting the secondary purification ponds directly to the lake to better link the lake's water tours and traffic to the expanded water area.

4) Developing the primary and secondary purification ponds into tourist attractions depending on local conditions.

5) To facilitate pollutant wash and flood control, setting control gates or designing stepping stones and overflow dams between the primary and secondary purification ponds, based on the water levels.

6) Constraining regular dredging activities within the primary purification pond to avoid ecological impacts on the lake.

In addition, in the upstream area of each stream, sewerage should be thoroughly drained, and the rainwater flow should be separated from the sewerage flow. Such practices will gradually restore the stream's watercollecting capacity and self-purification ability, release the pressure on water diversion from Qiantang River, and reduce operating costs. To avoid the negative consequences from conventional small-scale dredging operations, the eutrophic sediment on the bottom of the lake should be completely removed after the sewerage drainage and separation is thoroughly completed. Considering the long-term water balance and the optimization of water flows in the lake, if calculating based on the average annual runoff volume and current annual water diversion volume, there should be at least three water outlets for the water area to be expanded. If calculations are instead based on the average annual runoff volume and the originally designed annual water diversion volume, there should be a minimum of five outlets. 


\section{SPATIAL PLAN}

\subsection{Water Space Expansion}

The west plain of the lake occupies a total area of approximately 865 acres. From north to south, the streams are Jinsha, Longhong, Wuguitan and Chishan (see Figure 4). Historically, this region was once part of the lake but gradually silted up, and is thus easy to excavate. In the NHRSS, institutional land, residential land and farmland are mainly located in this area.

The south plain of the lake covers a total area of approximately 304 acres. The end of the diversion tunnel and the diverted water inlet of the lake are located in the western part of the region. Changqiao Stream is at the east (see Figure 4), with residential land and farmland distributed alongside it. Tourist attractions have been developed in the lakefront area.

\subsubsection{Land Suitability Analysis}

After analyzing the quantity of earthworks and land features with a comprehensive consideration of ecological, economic and social benefits, Table 4 shows the land suitability for the expansion of the water area. Figure 5 shows the available and suitable land, in the west and south plains of the lake, where the water can be expanded downstream of each stream.

Table 4. Land suitability for the expansion of water area

\begin{tabular}{|c|c|c|}
\hline $\begin{array}{l}\text { Land } \\
\text { Suitability }\end{array}$ & Land-use Feature & Classification Criterion \\
\hline $\begin{array}{l}\text { Suitable } \\
\text { Land }\end{array}$ & $\begin{array}{l}\text { - Farmlands and fishponds with } \\
\text { elevation less than or equal to } 10 \mathrm{~m} \\
\text { - Lands for tourism use with elevation } \\
\text { less than or equal to } 10 \mathrm{~m} \\
\text { - Green spaces with elevation less } \\
\text { than or equal to } 10 \mathrm{~m}\end{array}$ & $\begin{array}{l}\text { Requiring less excavation and being } \\
\text { the main non-point source in the } \\
\text { basin } \\
\text { Requiring less excavation and no land } \\
\text { replacement } \\
\text { Requiring less excavation and no land } \\
\text { replacement }\end{array}$ \\
\hline $\begin{array}{l}\text { Available } \\
\text { Land }\end{array}$ & $\begin{array}{l}\text { - Farmlands and fishponds with } \\
\text { elevation more than } 10 \mathrm{~m} \text { and less } \\
\text { than or equal to } 15 \mathrm{~m} \\
\text { - Lands for tourism use with elevation } \\
\text { more than } 10 \mathrm{~m} \text { and less than or equal } \\
\text { to } 15 \mathrm{~m} \\
\text { - Green spaces with elevation more } \\
\text { than } 10 \mathrm{~m} \text { and less than or equal to } 15 \\
\mathrm{~m} \\
\text { - Residential lands with elevation less } \\
\text { than or equal to } 10 \mathrm{~m}\end{array}$ & $\begin{array}{l}\text { Requiring more excavation, but being } \\
\text { the main non-point source in the } \\
\text { basin } \\
\text { Requiring more excavation but no } \\
\text { land replacement } \\
\text { Requiring more excavation but no } \\
\text { land replacement } \\
\text { Requiring less excavation but higher } \\
\text { relocation cost }\end{array}$ \\
\hline $\begin{array}{l}\text { Unsuitable } \\
\text { Land }\end{array}$ & $\begin{array}{l}\text { - Institutional lands with elevation } \\
\text { less than or equal to } 15 \mathrm{~m} \\
\text { - Tea plantations with elevation less } \\
\text { than or equal to } 15 \mathrm{~m} \\
\text { - Lands with elevation more than } 15 \\
\text { m }\end{array}$ & $\begin{array}{l}\text { Completing sewerage drainage and } \\
\text { requiring high relocation costs } \\
\text { Being the most important production } \\
\text { base of Longjing Tea } \\
\text { Requiring more excavation and being } \\
\text { difficult for water storage }\end{array}$ \\
\hline
\end{tabular}



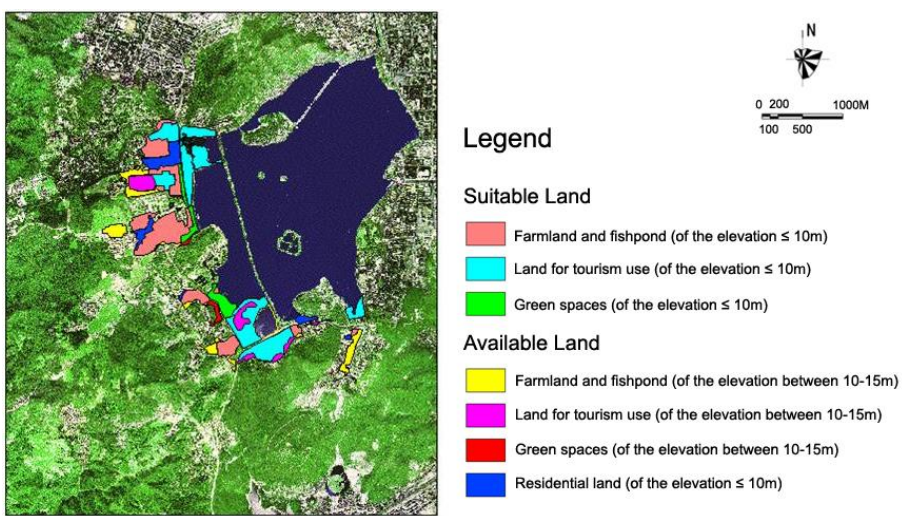

Figure 5. The suitable and available land for the expansion of the water area

\subsubsection{Shan-Shui Landscape Pattern Modelling}

The essence of West Lake's Shan-shui landscape lies in its preservation of the natural scenery. The expansion of the water area should conform to the NHRSS's natural features. To form a natural transition between the lake and the hills, a variety of fan-shaped water mouths should be excavated according to the natural topography, gulley direction and land use. Therefore, the study established a digital terrain model (a three-dimensional landscape model using the aerial image) and simulated the landscape for the expansion of water area by applying Audio Video Interleaved (AVI) files (Figure 6).
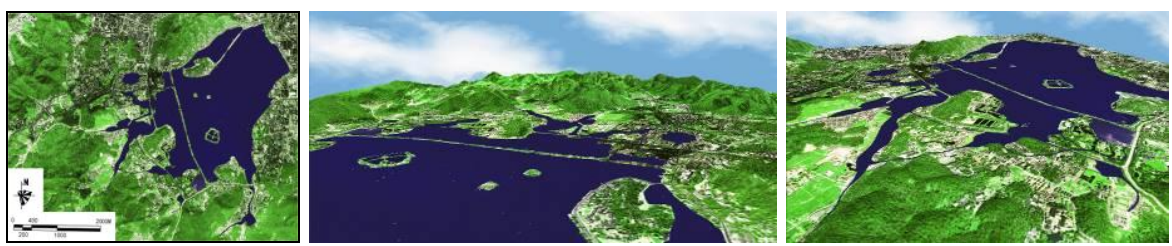

Figure 6. The simulated Shan-shui landscape for the expansion of water area

\subsection{Recreational Space Expansion}

The NHRSS's actual number of tourists has been exceeding the capacity proposed in the last master plan. Due to differences in the attractiveness of different scenic spots and the organization of touring activities, the distribution of the tourists has been in spatial disequilibrium for a long time (Table 5). The maldistribution of visitors has aggravated environmental pressure in particular areas. Traditionally, there were two ways to tour the NHRSS, either boating on the lake or roaming around the lake. The latter was further restricted to the north and south routes, with a large area in the west plain of the lake left undeveloped (Figure 7).

Table 5. Visitor statistics of the major tourist attractions in Hangzhou in 1999

\begin{tabular}{llll}
\hline Tour Route & Tourist Attraction & $\begin{array}{l}\text { Annual Visitors } \\
(10,000 \text { people })\end{array}$ & $\begin{array}{l}\text { Total Annual } \\
\text { Visitors (10,000 } \\
\text { people) }\end{array}$ \\
\hline Lake Tour & $\begin{array}{l}\text { Three Pools Mirroring the } \\
\text { Moon (San-tan-yin-yue }\end{array}$ & 207.98 & 207.98 \\
& &
\end{tabular}




\begin{tabular}{llll}
\hline Tour Route & Tourist Attraction & $\begin{array}{l}\text { Annual Visitors } \\
(10,000 \text { people })\end{array}$ & $\begin{array}{l}\text { Total Annual } \\
\text { Visitors }(10,000 \\
\text { people })\end{array}$ \\
\hline $\begin{array}{l}\text { North Route } \\
\text { (Around Tour) }\end{array}$ & Lingyin Klippe & & \\
& Yue Temple & 371.10 & 786.03 \\
& Botanic Garden & 214.28 & \\
& Huanglong Cave & 75.00 & \\
& Solitary Hill & 60.46 & \\
& Breeze-ruffled Lotus at & 34.04 & 633.46 \\
& Quyuan Garden & 31.15 & \\
& & & \\
South Route & Six Harmonies Pagoda & 108.29 & \\
(Around Tour) & Tiger Spring & 105.07 & \\
& Flower Harbour & 103.21 & \\
& Zoo & 92.94 & \\
& Children's Park & 66.61 & \\
& Yuhuang Mountain & 48.21 & \\
& Prince Bay & 39.72 & \\
& Orioles Singing in the & 37.41 & \\
& Willows & 32.00 & \\
& Six Harmonies Pagoda & & \\
\hline
\end{tabular}

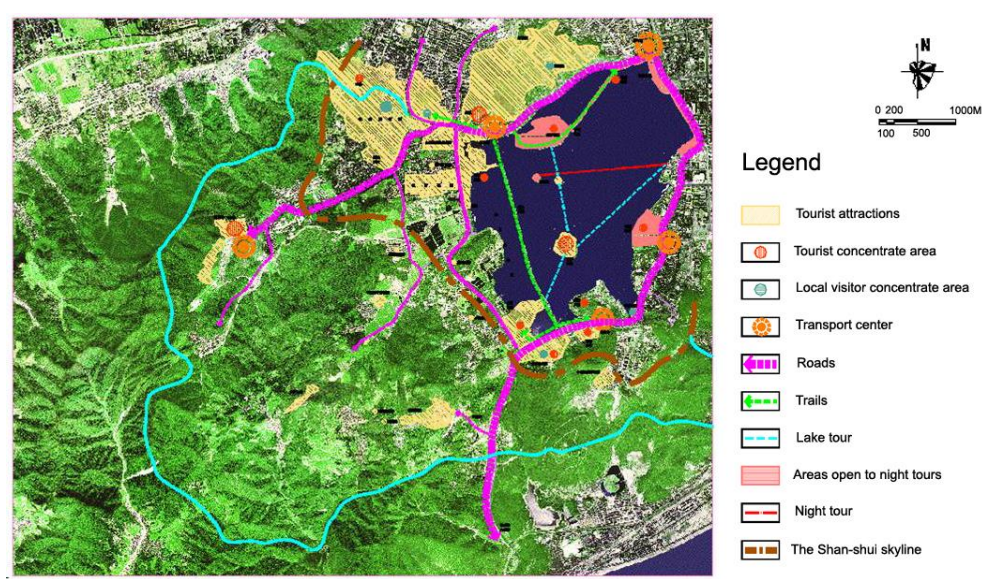

Figure 7. The existing distribution of visitors in the NHRSS

The NHRSS's individually dominated tourist composition requires a more reasonable scattering of tourist attractions and a more efficient organization of the tour route. The west area of the lake to be expanded is an important transitional zone between the lake and the hills. If part of Xishan Road is restored into an embankment, tourist service centers could be established along this new causeway. Additionally, trails could be developed in the western scenic areas, and new attractions could be built. This would create new recreational spaces in this area, and a number of new tour routes could be extended from the lake area into the western hills (Figure 8). This would achieve a more balanced distribution of tourists and ease the pressure on the existing north and south routes. 

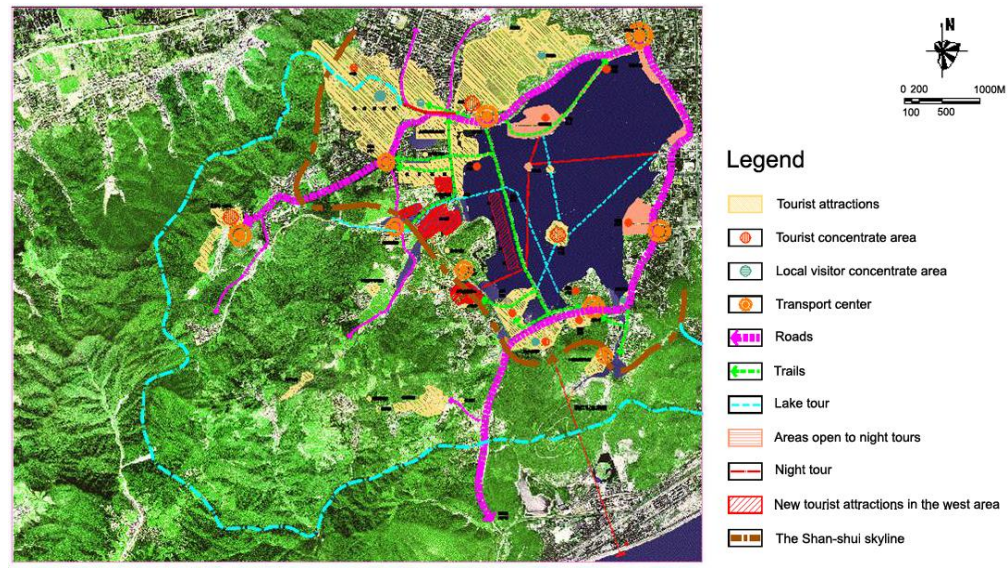

Figure 8. The expansion of recreational spaces in the west plain

\subsection{Infrastructure Renovation and Feasibility Analysis}

The proposed infrastructure renovation mainly involves the reconstruction of roads and sewerage pipelines in the region, as well as the existing diversion canal from Qiantang River. The reconstruction of roads should mainly focus on expanding the roads in the western recreational spaces, especially Xishan Road that would be again restored into embankment for pedestrians. Reconstruction of sewerage pipelines should extend the existing sewerage pipelines to improve the sewerage drainage and separate it from rainwater as it enters the streams, especially upstream of the three major tributaries (i.e., the Jinsha, Longhong and Changqiao streams). Furthermore, part of the existing sewerage pipelines along Xishan Road should be converted into a conduit to connect the aquaculture ponds of each stream, which would not impede the tourist boats from the lake. Reconstruction of the diversion canal from Qiantang River should aim to lead the diverted water into the nearby streams, i.e., Changqiao and Chishan streams, and then the aquaculture ponds in the downstream areas could be used to purify the diverted water before it enters the lake.

The estimated investment for the full implementation of the abovementioned measures was quite high. Calculating the costs of land acquisition, earthwork implementation, green space construction, residential house demolition and infrastructure reconstruction, the total amount was expected to reach 160 million RMB yuan. In addition, the general expense for the maintenance and dredging of the aquaculture ponds, and the operation of water diversion from Qiantang River would be approximately 500,000 RMB yuan per year. Therefore, detailed research should be conducted for further practices to develop this area rationally and flexibly, while minimizing costs when possible.

Additionally, planning efforts expect that tourism revenue would be substantial under this development. It was estimated that the environmental capacity would be expanded into 366,000 people per year. Based on tourist consumption in 1998, an increase of 165 million yuan per year in tourism revenue might be expected. Therefore, how attractions and tour organization could be rationally exploited, and objective growth of tourists could be ensured, would be major concerns for further interventions. 


\section{IMPLEMENTATION AND DISCUSSION}

\subsection{Water Restoration Practices and Effects}

In 1981, Hangzhou's local government established the West Lake Water Management Office of the NHRSS to monitor the water quality and supervise the lake's protection. In the initial twenty years, while a great deal of funds were invested and some projects organized to control the lake's eutrophication, the effects were not satisfactory and the eutrophication continued (Wu, Z. et al., 2008). In the early 2000s, the work began to focus on the comprehensive protection of the lake, which involved a series of demonstrations on environmental improvement and ecological restoration (Liu, Yin, 2017). Two National Major Special Research Projects on Treatment and Control of Water Pollution were launched. The first was the Ecological Restoration and Water Environment Improvement Project in the West Lake during the period from 2006 to 2010. The second was the Water Quality Improvement and Stable Ecosystem Transition Project in the West Lake during the period from 2011 to 2015 . Under the framework of these projects, and based on other studies, the local government implemented the following important practices and achieved striking ecological effects.

1) The dredging project was completed in 2002. An average depth of $0.5 \mathrm{~m}$ of silt on the bottom of the lake was dredged using a suction dredger to avoid secondary pollution, and the dredged silt piped 3 $\mathrm{km}$ away to the Jiang-yang-fan valley, which was dammed in 1999 for use as a dumping ground. The ecological effect of the dredging was obvious, for example $\mathrm{N}$ and $\mathrm{P}$ content in the sediment as well as the phytoplankton community, chlorophyll-a concentrations and trophic levels in the main lake areas decreased (Wu, Z. et al., 2008).

2) Construction of the Yuhuang Mountain Pre-treatment Site (see Figure 9) to treat water diverted from Qiantang River began in 2003. It can supply clean fresh water to renew the whole lake's water in one month. The operation of a depth integrated 2D numerical water quality high resolution model found that, using the treated water from Qiantang River, a 20 day water renewal would improve the water quality in most areas of the lake ( $\mathrm{Zhu} \& \mathrm{Han}$, 2010).

3) The comprehensive protection project in the area to the west of the lake was finished in 2003. It expanded more than 170 acres of wetland to purify the streams, developed nearly 200 acres of green space as the buffer, and rebuilt Xishan Road into the Yanggong Di Causeway that once existed (Shi, 2004). The area accommodated $5,000,000$ visitors in the opening week.

4) Ecological remediation of Changqiao Stream started in 2004 and was completed as an 11-acre wetland park (see Figure 9) that was opened to the public in 2009. The park integrated sewerage disposal techniques and a landscape garden to reduce the pollutant discharge from the southern valley into the lake (Wu, Y. \& Chen, 2008). The results from the operation of the Changqiao Stream Eco-Restoration Park showed that the stream water quality had been improved significantly (i.e., from worse than Grade V to Grade III) and the dissolved oxygen concentration in water had doubled (Chen, L., Rao, \& Sun, 2011). The project won the honor of Demonstration Project of National Key Practical Technologies of Environmental Protection (2006) and the Best Human Settlement in China (2010). 
It was selected in the 100-candidate list for Dubai International Award for Best Practices to Improve the Living Environment (2012).

5) Construction of 41.2 acre Jiang-yang-fan Ecological Park (see Figure 9) on the dredged silt conserved the natural succession on the site, which was opened to the public in 2010 (Wang \& Lin, 2011).

6) The 21-acre comprehensive treatment project of Longhong Stream (see Figure 9), which is the main stream flowing into the west plain of the lake, was the major part of Ecological Restoration and Water Environment Improvement Project in the West Lake. Its ecological purification system was composed of an ecological interception ditch, ecological purification ponds and a lakeside wetland zone (Liu, Yanzheng et al., 2015). The system began operating in 2012 and was proven to be successful at more than $40 \%$ better than the average removal rates of total nitrogen (TN) and total phosphorus (TP) (Liu, Yanzheng et al., 2015).

7) The demonstration of highly efficient nitrogen reduction to treat water diverted from Qiantang River at Yuhuang Mountain Pretreatment site (Liu, Yin, 2017)was a biological-ecological process using a modified mat pond, coupled with an integrated vertical-flow constructed wetland, and achieved over $50 \%$ of the average COD, $\mathrm{TN}$ and TP removal rates in the stable operating period beginning in 2012 (Kong et al., 2014).

8) Stable aquatic ecosystem transition was demonstrated by establishing the optimized submerged plant communities in the expanded west water area and the small south lake, which began in 2011 and was completed in 2015 (Liu, Yin, 2017).

9) Ecological restoration of the north inner lake was demonstrated by diverting cleaner water from the west inner lake using immersed tubes and establishing submerged plant communities in 2012 (Liu, Yin, 2017).

10) Water flow optimization in the lake was demonstrated by diverting cleaner water from the west to the east by immersed tubes to improve the hydrostatic water areas, which was completed in 2015 (according to the keynote report at the 2017 conference of the Chinese Society of Landscape Architecture by Zhiying Wu).

Through comprehensive management, the lake's eutrophication status was greatly reduced. By 2013, TP and TN concentrations had been decreased by $58 \% / 78 \%$ and $16.7 \% / 7.7 \%$ in the outer lake and the west inner lake, respectively, while the lake's transparency increased by $100 \%$ to 200\% (You et al., 2015). 


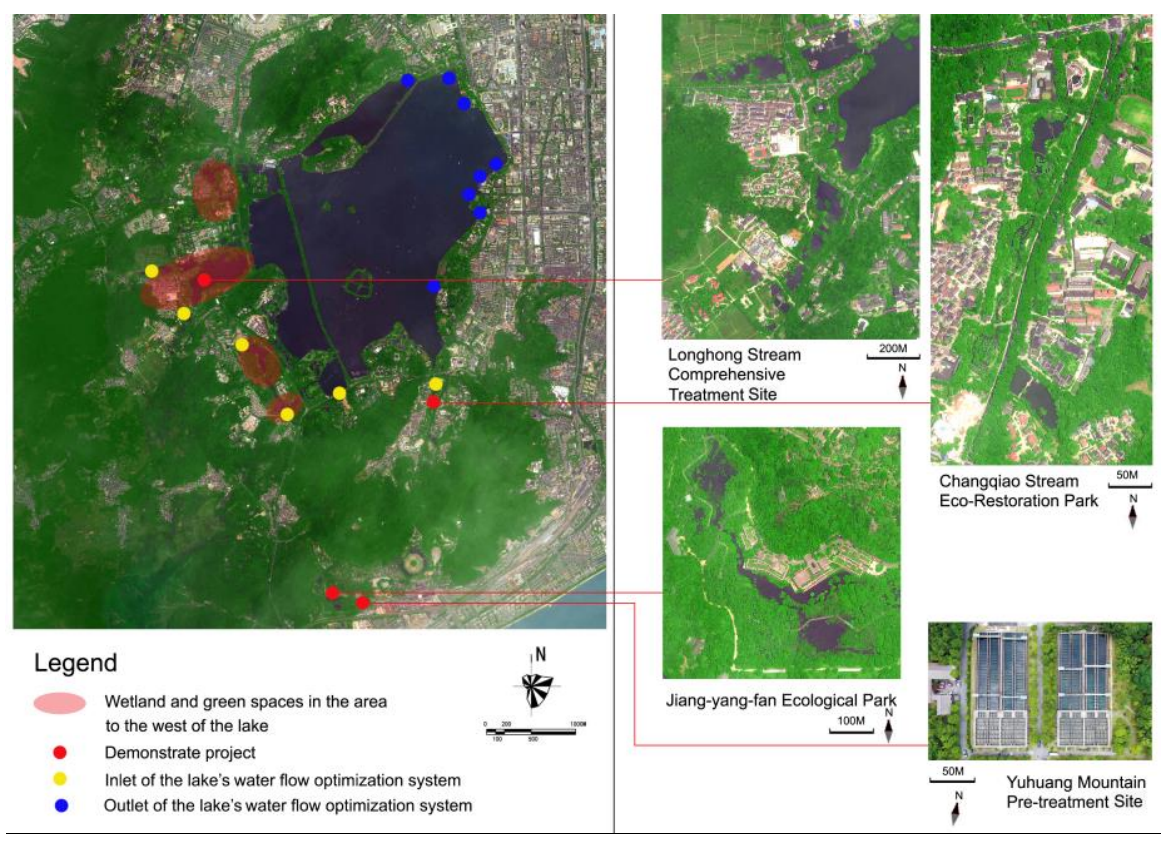

Figure 9. The locations of the important interventions (using maps downloaded from Auto Navi Map (AMAP))

\subsection{Reflections on the Implementation of Conceptual Planning}

In the recent decade, all the concepts proposed in the plan were well implemented in the interventions for the lake's ecological restoration, e.g., restoring the whole basin (not only the region to the west of the lake but also to the south), purifying the streams and the diverted river water before entering the lake, improving the water flows in the lake to shorten the lake retention time, and constructing a series of aquaculture ponds to purify and beautify the environment. Figure 10 is a flow chart that presents the lake's problems, the concepts of the planning and the treatment of its eutrophication before and after 2001. The West Lake is the lifeblood of the NHRSS and Hangzhou city. The essence of these new-found development practices lies in their important role in protecting the ecosystem of the lake, beginning with its water sources. No economic benefit could surpass the ecological benefits that would be provided by this plan. 


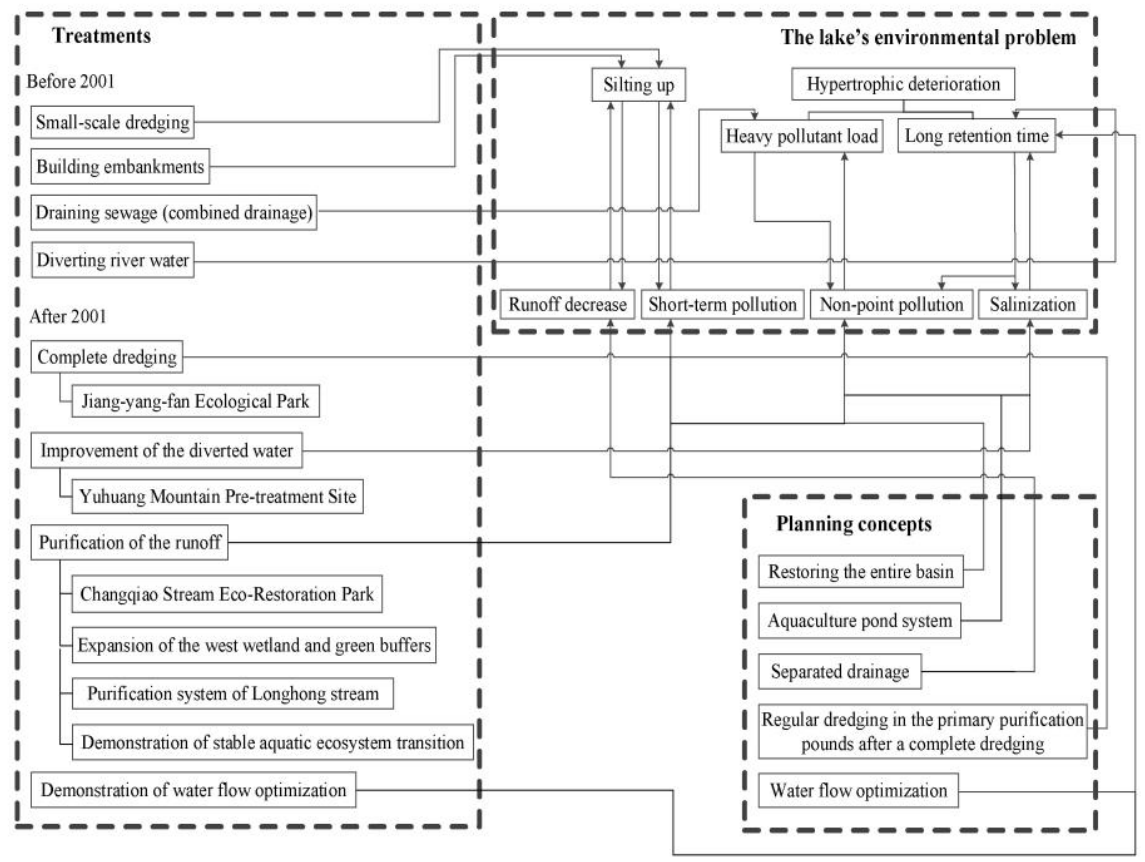

Figure 10. The flow chart on the research

The lake is an ecosystem. Sooner or later under natural conditions, it is bound to experience a lifecycle from growth and development (i.e., collecting water and nourishing lives) to degeneration and death (i.e., being silted up). Then, it transforms itself into another type of ecosystem. Only with significant effort, for example by following the laws of nature, relying on integrated efforts by the government, society and various enterprises, relying on human self-discipline and mutual supervision, can the process of degeneration and death of West Lake be delayed long enough for it to be rejuvenated and restored to vitality. It would undoubtedly be more responsible if the natural resilience of the lake's ecosystem could be restored instead of relying on external water diversion for long-term maintenance. This is the main idea of the plan transitioning from China's economy-centered concepts to environment-oriented development. It has also proven to be reasonable and effective over the 16-year implementation.

Conceptual planning that prioritizes protecting systems and increasing ecological resilience can help to achieve optimal ecosystem services and economic efficiency. By addressing the ecological and monetary quantification of its exact benefits, the scientific knowledge in the plan can be transferred to decision makers and stakeholders (Simoni, Vignoli, \& Mazzorana, 2017). This ecological conceptual planning for West Lake achieved both sets of goals.

Although this plan failed in the bid at that time, the actual remediation practice did not follow the bid-winning plan ${ }^{\circledR}$. The reason for this should be discussed from the perspective of China's conceptual planning system. In China, conceptual planning emerged in approximately 2000 as a kind of strategic planning that addresses the urgent development of the region. Therefore, it was generally sponsored by the local government and

(1) The bid-winning plan claimed to confine the development only in the west plain, and to improve the lake's water quality by replacing its water completely with water diverted from Qingshan Reservoir, a freshwater reservoir located to the east of the city with a linear distance of more than 30 kilometres away from the lake. 
supported by professionals and specialists. At that time, no one could ascertain the implementation and effect of this kind of planning activity. The consensus was that a conceptual plan's success should depend on 1) whether it can eventually become a virtual action guide to local or regional development and 2) whether it can be successfully connected with a statutory plan (e.g., a master plan that can be implemented through a compulsory top-down process supervised by the central government) (Zhang, 2002). In the case of West Lake, Tongji University's plan focused on the complex problem of the NHRSS, such that it transcended the bidwinning plan and eventually became the local government's action guide, and was gradually realized. Moreover, its concept of aquatic ecological remediation, and its proposal of changing the west and south plains into purification ponds and tourist attractions does not violate the NHRSS's statutory master plan, which proposed to build waterfront parks and expand the lake's water area.

However, the important practices that were implemented to restore the lake's ecosystem required significant technical support. Therefore, the NHRSS's managers organized teams of multidisciplinary experts and conducted in-depth and meticulous research. The successful restoration of West Lake indicated that, in addition to becoming a virtual action guide or linking to statutory planning, obtaining adequate multidisciplinary technical support is necessary for an ecological conceptual plan to become a best practice.

\section{CONCLUSION}

Conceptual planning became a type of popular strategic planning at the beginning of the 21st century in China. It is not a type of statutory planning, and, empirically, its successful implementation depends on two factors, 1) whether it can become a virtual action guide and 2) whether it can link to statutory planning.

Although Tongji University's conceptual planning for the west lake in Hangzhou did not win the bid in 2001, all of the concepts proposed in it have been well achieved in the lake's ecological restoration interventions from that point. Its success relies on rationally solving the essential problems facing local sustainable development and adequate multidisciplinary technical support.

The plan focused on the restoration of the aquatic environment and regarded environmental improvement as a precondition for the further development of tourism and the economy. The successful restoration of the lake's ecosystem is a solid achievement of the plan. In this sense, this plan should be regarded as a good case of ecological conceptual planning in China that helps to regenerate the local environment while realizing sustainable development.

\section{ACKNOWLEDGEMENTS}

Dr. Jiang Qiu, landscape designer Qinguang Song and Yinbo Gong, MLA Mingqi Yang and Dr. Wei Chen were members of the planning team. Dr. Zhiyong Zhong established the digital terrain model and created the AVI simulation. 


\section{REFERENCES}

Chen, B. (2003). "From Perspective Planning to Concept Planning ". Urban Planning Forum, 144(2), 1-4.

Chen, L., Rao, L., \& Sun, J. (2011). "Perfect Combination of Ecological Restoration and Landscape Architecture: Inspiration from Changqiao Stream Eco-Restoration Park". Chinese Landscape Architecture, 27(8), 1-7.

Jie, X., \& Bingyao, L. (2003). "The Thinking from Foreign Concept Plan". Urban Planning Forum, (1), 81-83.

Kong, L., He, F., Xia, S., Xu, D., Qiu, Z., \& Wu, Z. (2014). "Studies on Construction and Performance of the Qiantang River Water Diversion Denitrification Demonstration Project". Environmental Pollution \& Control, 36(11), 60-66.

Liu, Y. (2017). "The Explorations and Practices of the West Lake's Ecological Protection and Water Management in Hangzhou". Zhejiang Landscape Architecture, (2), 8-11.

Liu, Y., Zhang, X., He, T., Song, J., \& Wang, X. (2015). "Application of Ecological Restoration Technology in Comprehensive Treatment Project of Longhongjian Stream in Hangzhou City". China Water \& Wastewater, 31(22), 105-108.

Ouyang, Z., \& Wang, R. (1995). "The Review and Prospect of Ecological Planning". Journal of Natural Resources, 10(3), 203-215.

Shi, W. (2004). "Rediscovery of Secluded Area: The Comprehensive Protection Project in the Western Area of the West Lake". Construction Science and Technology, (5), 52-54.

Simoni, S., Vignoli, G., \& Mazzorana, B. (2017). "Enhancing Sediment Flux Control and Natural Hazard Risk Mitigation through a Structured Conceptual Planning Approach". Geomorphology, 291, 159-173. doi: https://doi.org/10.1016/j.geomorph.2017.01.026.

Steiner, F., \& Brooks, K. (1981). "Ecological Planning - a Review". Environmental Management, 5(6), 495-505.

Wang, X., \& Lin, Q. (2011). "The Story of the Design of Hangzhou Jiangyangfan Ecological Park". Landscape Architecture, (1), 18-31.

Wu, Y., \& Chen, J. (2008). "Demonstration Project of Water Pollution Treatment in Small Watershed: Ecological Remediation of Changqiao Steam, West Lake, Hangzhou". Journal of Lake Sciences, 20(1), 33-38.

Wu, Z., Yu, Z., Sheng, H., Xu, J., Han, Y., Xu, Y., . . Yao, J. (2008). "Ecological Effects of the Dredging in the West Lake, Hangzhou". Journal of Lake Sciences, 20(3), 277-284.

You, A., Wu, Z., Han, Z., Yang, J., \& Hua, L. (2015). "Spatial and Temporal Distributions and Variations of Nutrients in the West Lake,Hangzhou,after the Implementation of Integrated Water Management Program( 1985-2013)". Journal of Lake Sciences, 27(3), 371-377

Yu, K., \& Li, D. (1997). "The Pattern of Landscape Ecology for Urban, Rural and Regional Planning". Urban Planning Overseas, (3), 27-31.

Zhang, B. (2002). "A Critical Review of the Strategic Planning Practice in Contemporary China with Guangzhou, Nanjing and Jiangyin as the Cases". City Planning Review, 26(6), 63-68.

Zhao, M., \& Luan, F. (2003). "On the Methodology of Metropolitan Development Strategy Study". Urban Planning Forum, 143(1), 1-6.

Zhao, Y. (2001). "On the Theoretical Foundation and Methodology of Concept Planning". City Planning Review, 25(3), 38-52.

Zhu, J., \& Han, Z. (2010). "Study on Effect of Water Supply to Improve Total Phosphorus Concentration in the West Lake". Journal of Hydroelectric Engineering, 29(3), 137-142. 